\title{
Reproductive biology of the loliginid squid, Alloteuthis subulata, in the north-east Atlantic and adjacent waters
}

\author{
Lee C. Hastie ${ }^{1, a}$, Marianne Nyegaard ${ }^{1}$, Martin A. Collins ${ }^{2}$, Ana Moreno ${ }^{3}$, Joao M.F. Pereira ${ }^{3}$, \\ Uwe Piatkowski ${ }^{4}$ and Graham J. Pierce ${ }^{1}$ \\ 1 University of Aberdeen, Department of Zoology, Tillydrone Avenue, Aberdeen AB24 2TZ, UK \\ 2 British Antarctic Survey, High Cross, Madingley Road, Cambridge CB3 0ET, UK \\ 3 Instituto Nacional de Recursos Biológicos, INRB/L-IPIMAR, Avenida Brasilia, 1400 Lisboa, Portugal \\ ${ }^{4}$ Leibniz-Institut für Meereswissenschaften, Universität Kiel, Dsternbrooker Weg 20, 24105 Kiel, Germany
}

Received 17 July 2008; Accepted 17 November 2008

\begin{abstract}
A study of the reproductive biology of the loliginid squid, Alloteuthis subulata in the North Sea, Irish Sea and Portuguese waters was carried out. A predominance of small squid ( $<50 \mathrm{~mm} \mathrm{ML)} \mathrm{during} \mathrm{autumn} \mathrm{was} \mathrm{observed}$ in all three areas. Multi-modal size-frequency distributions were apparent in both sexes. The greatest complexity was observed in Portuguese waters, with males exhibiting possibly four or more modal size classes. Sexually mature squid were found throughout the year, with generally more mature squid in spring-summer and fewer in autumn-winter. In Portuguese waters, maturity in both sexes peaked in spring, whereas maturity in the other areas peaked in summer. Similar sizes-at-maturity were observed, with male squid maturing over a greater size range (40-125 mm ML) than females (30-50 mm ML). An apparent secondary peak in male maturity at $65 \mathrm{~mm}$ ML suggests two different size-maturation patterns in Portuguese waters. Estimates of potential fecundity in the Irish Sea ranged from 2200-13 500 eggs per female. Mean egg diameters of $0.45 \mathrm{~mm}$ and $1.55 \mathrm{~mm}$ were recorded for developing oocytes and mature ova, respectively. Three to four modal size classes of oocytes were apparent in each ovary. There was some indication of latitudinal effects on growth, maturation and reproduction of $A$. subulata across its geographic range. The greater complexity of size-structure in warmer waters suggests that water temperature may be the main factor involved, possibly through shorter incubation times, faster growth and maturation rates and extended spawning periods.
\end{abstract}

Key words: Distribution / Recruitment / Spawning / Cephalopod / Alloteuthis sp.

Résumé - Biologie de la reproduction chez l'encornet loliginidé, Alloteuthis subulata, du nord-est Atlantique et des mers adjacentes. Une étude de la biologie de la reproduction a été menée chez l'encornet loliginidé, Alloteuthis subulata de mer du Nord, mer d'Irlande et dans les eaux portugaises. Une prédominance de petits encornets $(<50 \mathrm{~mm}$ longueur du manteau) est observée durant l'automne dans les trois zones. Des distributions de fréquences des tailles multi-modales sont visibles chez les deux sexes. La plus grande complexité est observée dans les eaux portugaises, avec 4 modes ou plus dans les classes de tailles, chez les mâles. Les encornets sexuellement mûrs sont observés tout au long de l'année, en plus grande quantité au printemps-été et en moindre quantité en automne-hiver. Dans les eaux portugaises, la maturité atteint un maximum au printemps pour les deux sexes, tandis que dans les autres zones, elle est atteinte en été. Des tailles similaires à maturité sont observées, les mâles atteignant la maturité à une plus grande taille, entre 40 et $125 \mathrm{~mm}$ (ML), et chez les femelles entre 30 et $50 \mathrm{~mm}$ (ML). Un pic secondaire de maturité chez les mâles à 65 mm ML suggère que deux phénomènes de maturation à tailles différentes se dérouleraient dans les eaux portugaises. La fécondité potentielle en mer d'Irlande est estimée entre 2200 et 13500 œufs par femelle. Les diamètres moyens des œufs, $0,45 \mathrm{~mm}$ et $1,55 \mathrm{~mm}$, sont notés, respectivement pour les ovocytes en cours de développement et les ovocytes arrivant à maturité. Trois à quatre classes modales de tailles d'ovocytes sont apparentes dans chaque ovaire. Quelque indication concernant des effets de la latitude est observée sur la croissance, la maturation et la reproduction

\footnotetext{
a Corresponding author: nhi646@abdn.ac.uk
} 
de A. subulata dans son aire géographique. La grande complexité de la structure en tailles, dans les eaux plus chaudes, suggère que la température de l'eau peut être un facteur important, au travers de plus courtes périodes d'incubation, de plus rapides taux de croissance et de maturation, et de plus longues les périodes de ponte.

\section{Introduction}

The common European squid, Alloteuthis (Loligo) subulata (Lamarck), which is widely distributed in shallow coastal waters of the north-eastern Atlantic and Mediterranean Sea between $20^{\circ} \mathrm{N}$ and $60{ }^{\circ} \mathrm{N}$, is a small loliginid species with a maximum recorded mantle length (ML) of $\sim 200 \mathrm{~mm}$, including the long narrow tail (Roper et al. 1984; Anderson 2008). It is the most common cephalopod species found in the central and southern North Sea, constituting $\sim 90 \%$ of overall numbers caught in research trawls (de Heij and Baayen 1999) and it also appears to be abundant in the English Channel (Rodhouse et al. 1988) and Irish Sea (Nyegaard 2001). Alloteuthis subulata is often caught and landed with juvenile Loligo spp. in a few directed squid fisheries (e.g. in the Moray Firth, Scotland) and occurs in the by-catches of several demersal trawl fisheries across its range. In Portugal it is the most abundant cephalopod species, but the biomass is thought to be relatively small. The commercial value is generally low due to the small size and it is discarded in most areas (Fernandes et al. 2008). In southern Spain however, Alloteuthis spp. are landed and marketed (WGCEPH Report 2005) Although little is known about the ecology of $A$. subulata, it is likely to be an important species in coastal ecosystems since it appears to be an abundant predator of small fish and is itself preyed upon by a number of larger marine animals. It is the most abundant cephalopod species recorded in stomach contents of demersal fish in UK waters (Hislop et al. 1991; Daly et al. 2001) and is also considered to be an important item in the diet of demersal fish in Spanish waters (Velasco et al. 2001).

Few studies of the reproductive biology of A. subulata have been undertaken. In Portuguese waters, progressive maturation occurs from winter to late spring, with the males maturing slightly earlier than the females (Moreno 1990, 1995). In some areas, there may be several distinct spawning events each year. For example, in the English Channel, there appear to be three spawning groups of female A. subulata that spawn in spring, summer and autumn, with two recruitment events in spring and summer. The pattern in adult males is more complex, with no regular pattern observed (Rodhouse et al. 1988). In the Irish Sea, spawning occurs mainly in spring and summer, with a possible minor spawning event in autumn (Nyegaard 2001). In the North Sea, the spawning season is restricted to June-July, with hatchlings appearing in plankton samples towards the end of July (Yau 1994). In early summer, male and female $A$. subulata arrive together inshore. Spawning probably occurs earlier off the west coast of Scotland than in the North Sea (Yau 1994).

Based on the perceived ecological importance and fishery potential of $A$. subulata, further investigations of the life history and ecology of this species are worthwhile. Since the embryonic development and hatching, growth and maturation and timing of reproduction of many cephalopod species may be influenced by temperature (Boyle 1983), it would also be interesting to compare squid from different geographic areas. This paper describes opportunistic investigations of the reproductive biology of $A$. subulata from the northeast Atlantic and adjacent waters, based on specimens taken in the North Sea, Irish Sea and Portuguese waters between 1990 and 2005. Possible explanations for observed spatial and temporal variations in growth and maturation patterns are also discussed.

\section{Materials and methods}

\subsection{Collection of material}

Location information and seasonal/annual mean sea surface temperature (SST) values for the three study areas are provided (Table 1). Samples of A. subulata were obtained during routine juvenile ground-fish and bottom-trawl surveys of the northeast Atlantic and adjacent waters (1990-2005), carried out by Fisheries Research Services (FRS, Scotland), Bundesforschungsantalt für Fischerei (BFAFi, Germany), Department of Agriculture and Rural Development (DARD, Northern Ireland) and Instituto Nacional de Recursos Biológicos (INRB/LIPIMAR, Portugal). The research vessels involved were $R V$ Scotia (FRS) and $R V$ Walther Herwig III (BFAFi) - North Sea, $R V$ Lough Foyle (DARD) - Irish Sea, $R V$ Noruega (IPIMAR) and $R V$ Mestre Costeiro (IPIMAR) - Portuguese waters (Table 2).

\subsection{Biological data}

Squid mantle lengths $(M L, \mathrm{~mm})$ and body weights $(B W, \mathrm{~g})$ were recorded. Specimens were then opened and examined under a dissecting microscope and sexed (except for very small, "immature" specimens with no identifiable reproductive organs). Each squid was also assigned a maturity stage, based on the relative size and appearance of their reproductive organs using a simplified version of a maturity scale developed for loliginid squid (Boyle and Ngoile 1993), stage 0: "immature" (sex unknown), 1: "immature" (sexed), 2: "maturing" (equivalent to stages 2-3 in Boyle and Ngoile 1993) and 3: "mature" (equivalent to stages 4-5 in Boyle and Ngoile 1993). Maturity ogives were fitted by least-squares (residuals).

Data from the opportunistic samples were pooled according to geographic region (North Sea, Irish Sea, Portuguese waters) and season (spring: March-May, summer: June-August, autumn: September-November, winter: December-February).

\subsection{Potential fecundity}

A sub-sample of 11 mature female A. subulata was taken from the Irish Sea in March 2000. Specimens were frozen onboard the RV Lough Foyle and maintained for 2-7 days at $20{ }^{\circ} \mathrm{C}$. These were later defrosted, measured $(M L, B W)$, fixed in $10 \%$ formalin for 2-7 days and then stored in $70 \%$ ethanol. 
Table 1. Locations and seasonal/annual mean sea surface temperature (SST) values of the three Alloteuthis subulata study areas.

\begin{tabular}{lccccccc}
\hline & & \multicolumn{5}{c}{ Mean SST $\left({ }^{\circ} \mathrm{C}\right)^{1}$} \\
\cline { 4 - 8 } Area & ICES Div. & Lat $\left({ }^{\circ} \mathrm{N}\right)$ & Spring & Summer & Autumn & Winter & Annual \\
\hline North Sea & $4 \mathrm{a}$ & $57-62$ & 7.6 & 12.3 & 11.1 & 7.8 & 9.7 \\
Irish Sea & $7 \mathrm{a}$ & $52-55$ & 8.4 & 13.7 & 13.3 & 8.6 & 11.0 \\
Portugal & $9 \mathrm{a}$ & $36-43$ & 15.0 & 18.2 & 18.0 & 14.6 & 16.5 \\
\hline
\end{tabular}

${ }^{1}$ Source: ICES/NCAR.

Table 2. Pooled samples of Alloteuthis subulata collected during fishery research trawl surveys (1990-2005).

\begin{tabular}{lcccccccc}
\hline & \multicolumn{3}{c}{ Mesh $^{1}$} & Nquid & & \\
Vessel & Area & $(\mathrm{mm})$ & Period & $N^{2}$ & Male & Female & Immature & Total \\
\hline$R$ S Scotia & North Sea & 35 & $1990-1995$ & 8 & 347 & 350 & 227 & 924 \\
$R$ Walther Herwig III & North Sea & 35 & $1998-1999$ & 3 & 983 & 815 & 47 & 1845 \\
RV Lough Foyle & Irish Sea & 20 & $1993-2000$ & 6 & 1184 & 1132 & 1529 & 3845 \\
RV Mestre Costeiro & Portugal & $20 / 40$ & $1990-2001$ & 8 & 627 & 517 & 45 & 1189 \\
RV Noruega & Portugal & $20 / 40$ & $1990-2005$ & 5 & 134 & 216 & 8 & 358 \\
\hline
\end{tabular}

${ }^{1}$ Codend/liner net mesh size. ${ }^{2}$ Pooled samples, corresponds to number of cruises.

Each squid was then dissected and the ovary and oviducal complex (oviducts + oviducal glands) were excised.

Numbers of developing eggs (oocytes) in the ovaries were determined volumetrically. Ovary volume $(O V$, to nearest $0.1 \mathrm{ml})$ was estimated by displacement of $70 \%$ ethanol in a graduated cylinder. From each ovary, three equally-spaced samples of tissue were taken (from the anterior, middle and posterior regions), dehydrated with ethanol and embedded in historesin. Histological cross sections $(2.5 \mu \mathrm{m})$ of these were then taken, mounted and stained with $1 \%$ Toluidine Blue in $1 \%$ Bovax. Enlarged ( $\times 4$ magnif.) cross-sectional areas were measured $\left(A, \mathrm{~mm}^{2}\right)$ using a microscope video camera linked to a PC with image analysis software. Larger images $(\times 86)$ were used to measure the diameters of all oocytes $(\mu \mathrm{m})$ in each section. An average of the longest axis and the perpendicular axis was taken to represent oocyte diameter. Mean oocyte diameter and number of oocytes per area was calculated for each section. The number of oocytes per unit volume of ovary was then estimated (Laird and Priede 1986):

$$
N_{v}=N_{a} /(D+h)
$$

$N_{v}$ : number of oocytes per unit volume ovary, $N_{a}$ : total count of oocytes per unit area, $D$ : diameter of oocytes, $H$ : thickness of histological section.

The total number of oocytes per ovary $\left(N_{o v}\right)$ is:

$$
N_{o v}=N_{v} O V
$$

OV: ovary volume

Numbers of mature, post-vitellogenic eggs (ova) in the oviducal complexes $\left(N_{o d}\right)$ were determined manually, by dissecting the oviducts and oviducal glands and counting the ova under low magnification $(\times 10)$. The numbers of oocytes and ova were then combined to obtain an overall estimate of potential fecundity $(P F)$ :

$$
P F=N_{o v}+N_{o d}
$$

Size of mature, post-vitellogenic eggs (ova) in the oviducal complexes of five mature females collected in Portugal on the $6^{\text {th }}$ May 2005 was determined by dissecting the oviducts and oviducal glands, excising the ova and measuring under low magnification $(\times 10)$. The longest axis and its perpendicular axis, were measured and averaged to represent oocyte diameter from 50 ova of each specimen (250 in total).

\section{Results}

Overall numbers of squid (A. subulata) collected in the three geographic areas are provided, along with details of the vessels, gear (mesh size) and sampling period (Table 2). Pooled samples of 2769, 3845 and 1547 squid were taken from the North Sea, Irish Sea and Portuguese waters, respectively.

\subsection{Sex ratio}

Observed seasonal sex ratios $(M / F)$ ranged from 0.47 to1.31. Overall, slightly more male squid $(M / F=1.04$ to 1.14) were recorded in all three areas, although females may be relatively more abundant during spring in Portugal $(M / F=0.76)$ and in summer in the North Sea and Irish Sea $(M / F=0.76$ and 0.78 , respectively). No other spatial or seasonal trends in sex ratio were apparent.

\subsection{Size-frequency distributions}

The size-frequency distributions of the North Sea and Portuguese samples were quite similar, with both exhibiting a modal size class of 51-60 mm $M L$. By contrast, the Irish Sea sample comprised relatively small squid (modal class 31$40 \mathrm{~mm} M L$ ). Similar size ranges and additional size modes (see below) were observed in all three samples. A predominance of small squid ( $<50 \mathrm{~mm} M L$, both sexes) during autumn was observed in all three areas (Fig. 1). However, relatively large numbers of small squid were also found during winterspring in the North Sea, during summer in the Irish Sea, and 
MALES

\section{North Sea}
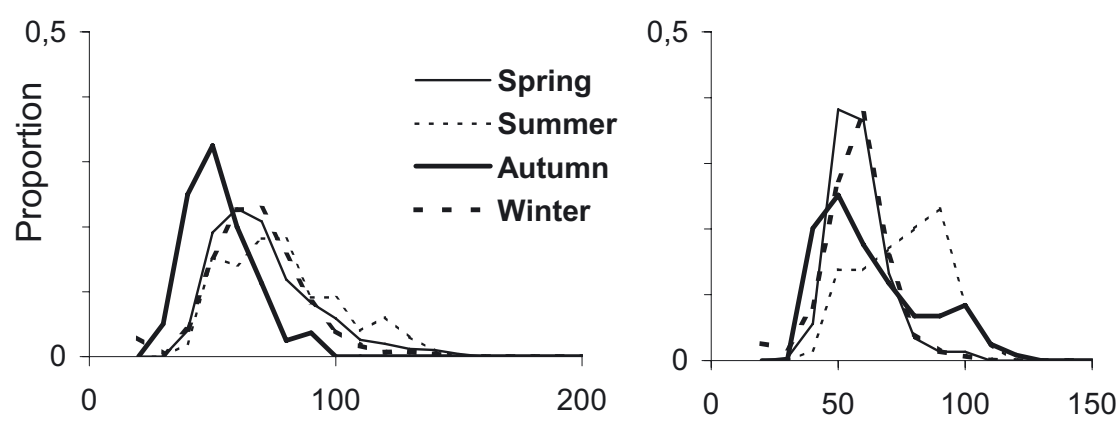

Irish Sea
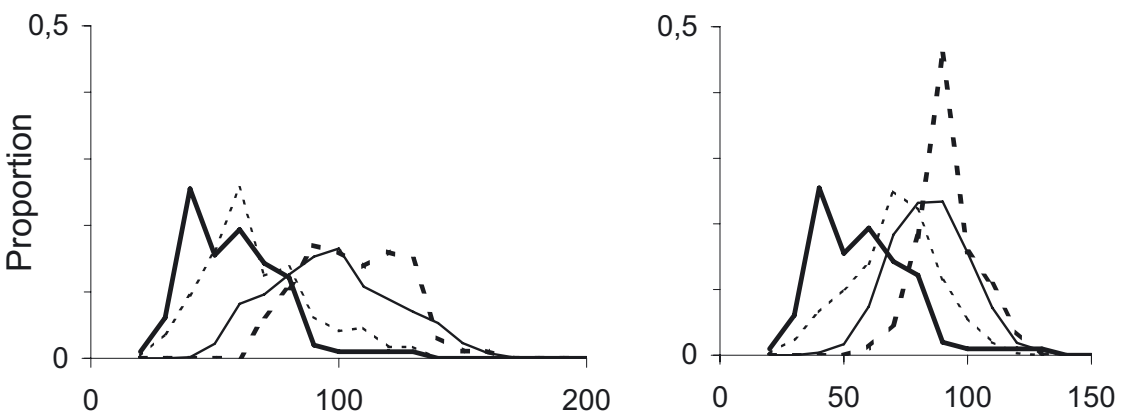

Portugal
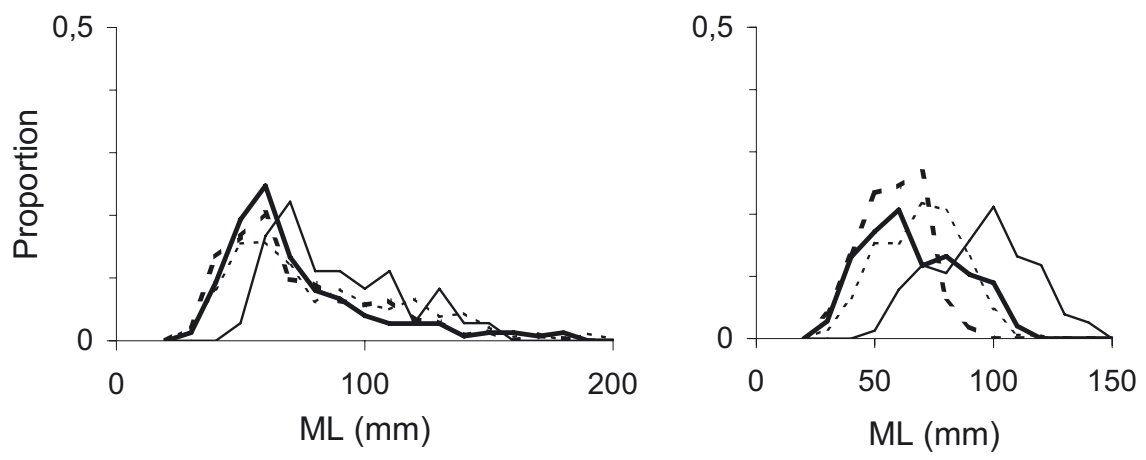

Fig. 1. Seasonal size-frequency distributions of Alloteuthis subulata recorded in North Sea, Irish and Portugal for males and females. Pooled sample sizes provided in Table 2.

during summer and winter in Portuguese waters. Large squid appeared to be relatively more abundant during summer in the North Sea, during winter-spring in the Irish Sea, and during spring in Portuguese waters. Within each area, seasonal patterns of abundance were generally similar in both sexes, except in Portuguese waters where large females appeared to be relatively more abundant during spring (Fig. 1).

Bi-modal size-frequency distributions were apparent in all three areas in both sexes, particularly during autumn. In the Irish Sea and Portuguese waters, male squid exhibited multimodal size profiles. The greatest complexity was apparent in Portuguese waters, with males exhibiting four or more modal size-classes (Fig. 1). Females exhibited bi-modal profiles in all areas, although bi-modality was more pronounced and persistent (occurring in all seasons) in Portuguese waters.

\subsection{Length-weight relationships}

Observed length-weight relationships $\left(B W=a M L^{b}\right)$ were generally similar in all three areas, especially for female squid (Table 3). Mature females were relatively heavier than mature males but exhibited a smaller maximum size (Fig. 2): $M L_{\max }<$ $150 \mathrm{~mm}$ (females) and $>200 \mathrm{~mm}$ (males), $B W_{\max }>22 \mathrm{~g}$ (both sexes). Geographical differences in weight-at-length were also noted (Fig. 2); the general pattern in small males $(<75 \mathrm{~mm}$ $M L)$ and females was Portuguese $>$ Irish Sea $>$ North Sea. However, in large males $(>75 \mathrm{~mm} M L)$ this trend was reversed (Fig. 2a). ANCOVAs on ln-transformed datasets indicated significant spatial differences in length-weight equations for males $\left(F_{(2,2905)}=48.31, p<0.001\right)$ and females $\left(F_{(2,579)}=\right.$ 94.55, $p<0.001)$. Within each area, however a number of significant "seasonal" differences were also detected by 
Table 3. Computed length-weight parameters of $A$. subulata $(B W=$ $\left.a M L^{b}\right)$

\begin{tabular}{ccccc}
\hline Area & $n$ & $a$ & $b$ & $r^{2}$ \\
\hline \multicolumn{5}{c}{ MALES } \\
North Sea & 1275 & 0.0047 & 1.5924 & 0.824 \\
Irish Sea & 1058 & 0.0118 & 1.3916 & 0.910 \\
Portugal & 574 & 0.0268 & 1.1947 & 0.820 \\
\hline \multicolumn{5}{c}{ FEMALES } \\
North Sea & 1029 & 0.0027 & 1.7721 & 0.797 \\
Irish sea & 1035 & 0.0022 & 1.8351 & 0.915 \\
Portugal & 517 & 0.0025 & 1.8250 & 0.923 \\
\hline
\end{tabular}

ANCOVA, (not shown here, since consistent patterns were not observed for either sex).

\subsection{Sexual maturation}

Although some of the pooled monthly samples were quite small, mature squid were found throughout the year. The proportions of mature squid ranged from $\sim 0.1-0.7$ in all areas. However, similar seasonal patterns were observed, with relatively more mature squid in spring-summer and fewer in autumn-winter. Some sexual and spatial differences were observed. For example, maturity appeared to be more prevalent in males than females in the North Sea during winter. In the Irish Sea, male maturity peaked in spring, whilst female maturity peaked in summer. In Portuguese waters, maturity in both sexes peaked in spring whereas maturity in the other areas (except for Irish Sea males) peaked in summer. An apparent predominance of small, immature squid in the North Sea and Irish Sea during autumn was observed (Figs. 3a-d). This was not recorded in the Portuguese samples, although substantial proportions (20-25\%) of these were immature during all seasons except spring (Figs. 3e-f).

Although mature squid were found throughout the year in the North Sea, the proportion of squid that were mature was generally lower than in the other areas. In male squid, for example, maturity levels $>20 \%$ were only recorded in two seasons in the North Sea (summer/winter), and in three seasons in the Irish Sea (spring/summer/winter) and Portuguese waters (spring/summer/autumn). In female squid, maturity levels $>20 \%$ were recorded during one season in the North Sea (summer), during three seasons in the Irish Sea (spring/summer/winter) and during all four seasons in Portuguese waters (Fig. 3).

Similar size-maturity ogives were observed, with male squid maturing over a greater size $(M L)$ range than females (Fig. 4). Length and weight data for mature squid are provided (Tables 4-5). Males exhibited similar sizes-at-maturity $\left(M L_{50}\right)$ in the three areas, although mature males in the Irish Sea were larger and heavier on average (Table 4). In general, males appeared to mature at a smaller size during summerautumn than in other seasons. Males appeared to start maturing at minimum sizes $\left(M L_{\text {min }}\right)$ of $40-45 \mathrm{~mm}$ in the three areas. An apparent secondary peak in male maturity at $65 \mathrm{~mm}$ $M L$ suggests that two different size-maturation patterns may
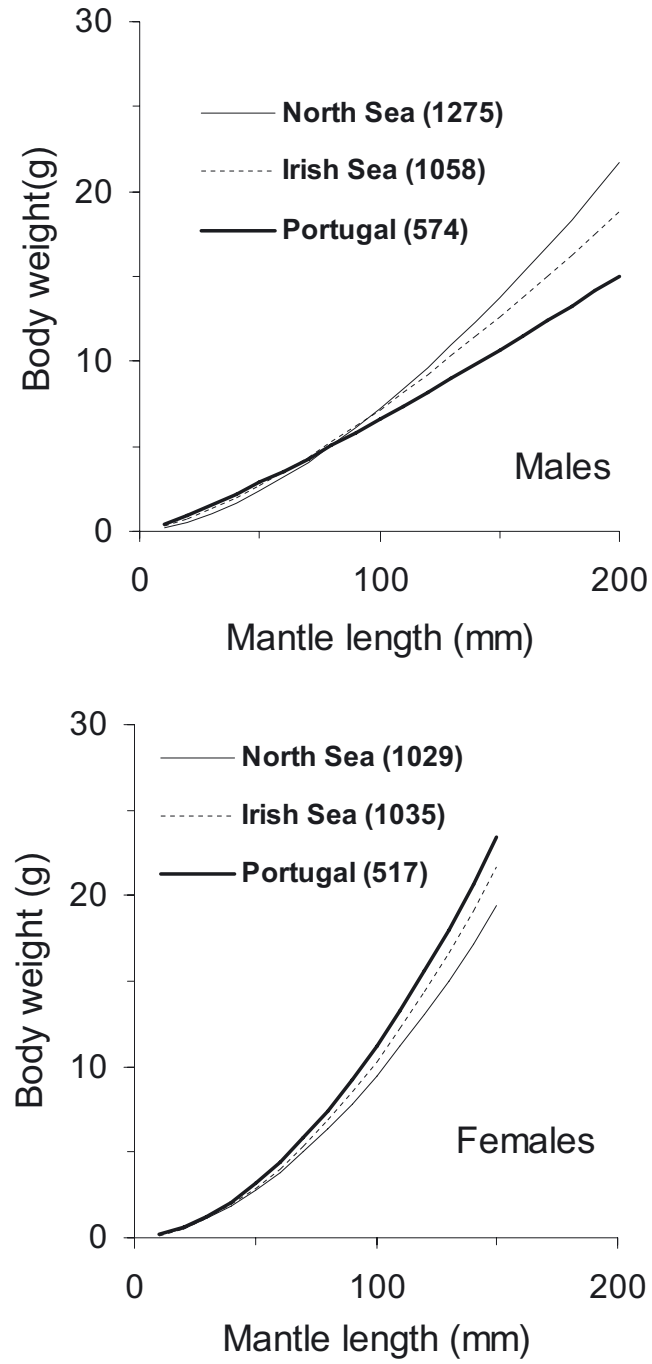

Fig. 2. Fitted length-weight lines of Alloteuthis subulata. Pooled sample sizes in parentheses.

occur in Portuguese waters (Fig. 4). Other possible maturity peaks, at larger sizes $(125-135 \mathrm{~mm} \mathrm{ML})$ were observed in all areas, although these were based on small numbers of very large squid (and therefore may be due to sampling error). Similar patterns were observed for females, with the largest and heaviest mature females being recorded in the Irish Sea (Table 5). Respective (overall) $M L_{\text {min }}$ values of $32 \mathrm{~mm}, 34 \mathrm{~mm}$ and $47 \mathrm{~mm}$ were recorded for the North Sea, Irish Sea and Portuguese waters, indicating that females may start maturing at a larger size in the latter area. The smallest female $M L_{50}$ values were recorded during the summer months in all areas. There also appeared to be some spatial variation in overall size-atmaturity of females, with $M L_{50}$ values for North Sea > Irish Sea $>$ Portuguese samples (Table 5, Fig. 4b).

\subsection{Inter-annual variation}

Two sets of monthly samples obtained were large enough to compare $M L_{50}$ and mean $M L$ estimates of squid caught in the same month, by the same vessel, in different years 


\section{Males}

a)

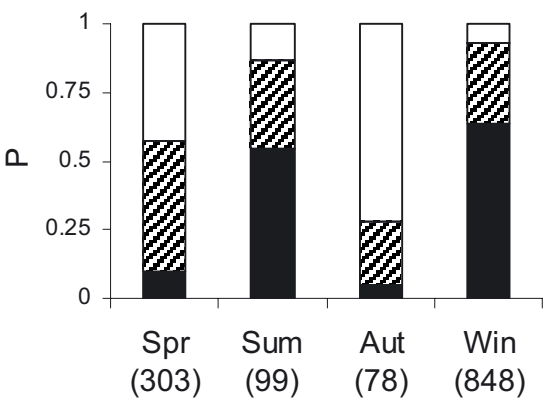

Females

b)

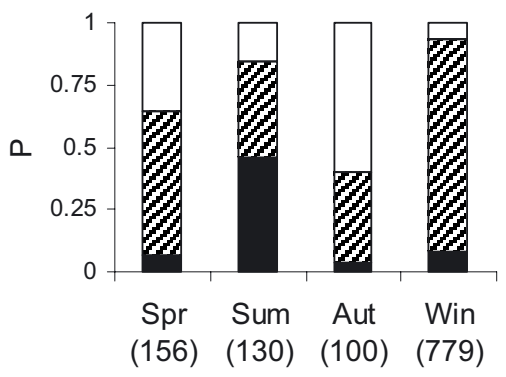

c)

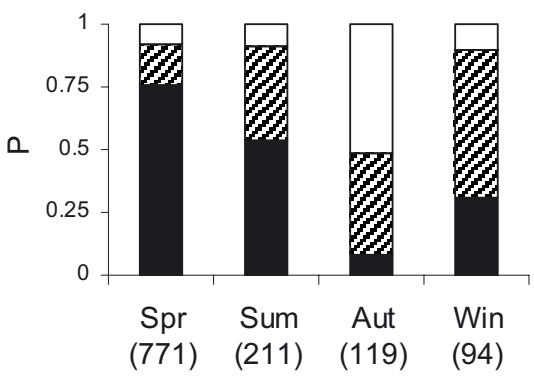

Irish Sea

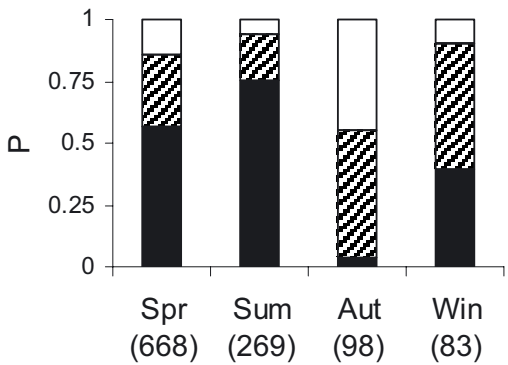

e)

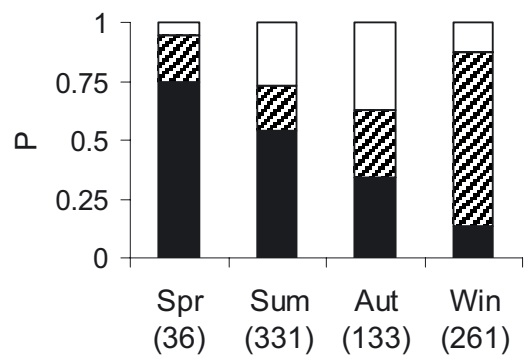

Portugal

f)

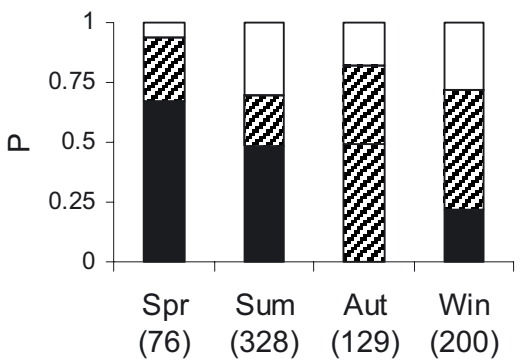

Fig. 3. Seasonal proportions of immature (white), maturing (hatched) and mature (black) Alloteuthis subulata observed in males and females. Pooled sample sizes in parentheses.

(Table 6). In the North Sea (January) and the Irish Sea (March), inter-annual differences in $M L_{50}$ were apparent in males but not in females. One-way ANOVAs indicated no significant differences in $M L$ for either sex in the North Sea between 1998 and 1999. In the Irish Sea, however, both sexes were significantly larger in 2000 than in 1993 (males: $F_{(1,776)}=63.22$, $p<0.001$; females: $\left.F_{(1,681)}=132.38, p<0.001\right)$. Monthly (March) mean SST values of $6.9^{\circ} \mathrm{C}$ and $7.9^{\circ} \mathrm{C}$ were recorded in the Irish Sea during 1993 and 2000, respectively, suggesting that the warmer conditions may have accelerated growth. $A N$ COVAs on ln-transformed North Sea datasets indicated no significant differences in length-weight equations for either sex between 1998 and 1999 (males: $F_{(1,908)}=0.18, p=0.670$; females: $F_{(1,687)}=0.18, p=0.673$ ). Monthly (January) mean SST values of $8.4{ }^{\circ} \mathrm{C}$ and $7.9{ }^{\circ} \mathrm{C}$ were recorded in the North Sea during 1998 and 1999, respectively. In the Irish Sea datasets, significant differences in length-weight equations were detected in both males $\left(F_{(1,774)}=4.21, p<0.05\right)$ and females $\left(F_{(1,679)}=28.75, p<0.001\right)$ between 1993 and 2000 .

\subsection{Potential fecundity}

Estimates of potential fecundity for the Irish Sea squid are summarised in Table 7 . Overall $P F$ values ranged from $\sim 2200-13500$ eggs per female (mean $\sim 5900 \pm 970$ SE). There was no significant relationship $(p>0.05)$ between $P F$ and body size $(M L, B W)$ although sample size was small $(n=11)$. Mean egg diameters of $0.45 \pm 0.04 \mathrm{~mm}$ and $1.55 \pm 0.04 \mathrm{~mm}$ were recorded for developing oocytes and mature ova, respectively. Mean diameter of mature ova in the Portuguese sample was $1.47 \pm 0.23 \mathrm{~mm}$. As Figure 5 shows, the ovarian egg-size distributions were highly skewed, due to a predominance of 
Table 4. Seasonal size-at maturity data recorded for male A. subulata.

MALES

\begin{tabular}{|c|c|c|c|c|c|c|c|c|c|c|c|}
\hline \multirow[b]{3}{*}{ Season } & \multirow[b]{3}{*}{ Area } & \multirow[b]{3}{*}{$N$} & \multirow{3}{*}{$\begin{array}{l}M L_{50} \\
(\mathrm{~mm})\end{array}$} & \multicolumn{8}{|c|}{ Size-at-maturity } \\
\hline & & & & \multicolumn{4}{|c|}{$M L(\mathrm{~mm})$} & \multicolumn{4}{|c|}{$W t(\mathrm{~g})$} \\
\hline & & & & $N$ & Mean & SD & Range & $N$ & Mean & SD & Range \\
\hline \multirow[t]{3}{*}{ Spring } & North Sea & 303 & 98 & 36 & 97.8 & 23.6 & $58-146$ & 36 & 7.4 & 2.7 & $3.1-13.5$ \\
\hline & Irish Sea & 771 & 77 & 557 & 102.2 & 22.0 & $44-131$ & 557 & 7.5 & 2.1 & $2.2-17.3$ \\
\hline & Portugal & - & - & - & - & - & - & - & - & - & - \\
\hline \multirow[t]{3}{*}{ Summer } & North Sea & 99 & 65 & 54 & 83.5 & 20.4 & $50-130$ & 54 & 5.3 & 2.0 & $1.3-10.3$ \\
\hline & Irish Sea & 211 & 60 & 113 & 77.6 & 20.2 & $47-130$ & 113 & 5.0 & 1.4 & $2.1-8.2$ \\
\hline & Portugal & 331 & 69 & 186 & 98.0 & 36.8 & $39-215$ & 150 & 6.1 & 2.2 & $1.8-11.8$ \\
\hline \multirow[t]{3}{*}{ Autumn } & North Sea & - & - & - & - & - & - & - & - & - & - \\
\hline & Irish Sea & - & - & 11 & 79.1 & 15.5 & 54-104 & 11 & 7.4 & 1.6 & $4.6-9.8$ \\
\hline & Portugal & 133 & 53 & 83 & 83.9 & 32.1 & $46-177$ & 33 & 6.5 & 2.5 & $2.7-11.8$ \\
\hline \multirow[t]{3}{*}{ Winter } & North Sea & 848 & 90 & 206 & 80.4 & 20.8 & $45-146$ & 207 & 5.5 & 2.2 & $1.8-14.2$ \\
\hline & Irish Sea & - & - & - & - & - & - & - & - & - & - \\
\hline & Portugal & 261 & 120 & 34 & 96.2 & 39.3 & $44-174$ & 26 & 5.6 & 1.5 & $2.6-8.2$ \\
\hline \multirow[t]{3}{*}{ Overall } & North Sea & 1250 & 77 & 296 & 84.3 & 21.8 & $45-146$ & 297 & 5.7 & 2.3 & $1.3-14.2$ \\
\hline & Irish Sea & 1101 & 78 & 681 & 97.8 & 23.5 & $44-175$ & 681 & 7.2 & 2.3 & $2.1-22.2$ \\
\hline & Portugal & 725 & 78 & 303 & 92.8 & 34.2 & $39-215$ & 209 & 6.3 & 2.3 & $1.8-12.2$ \\
\hline
\end{tabular}
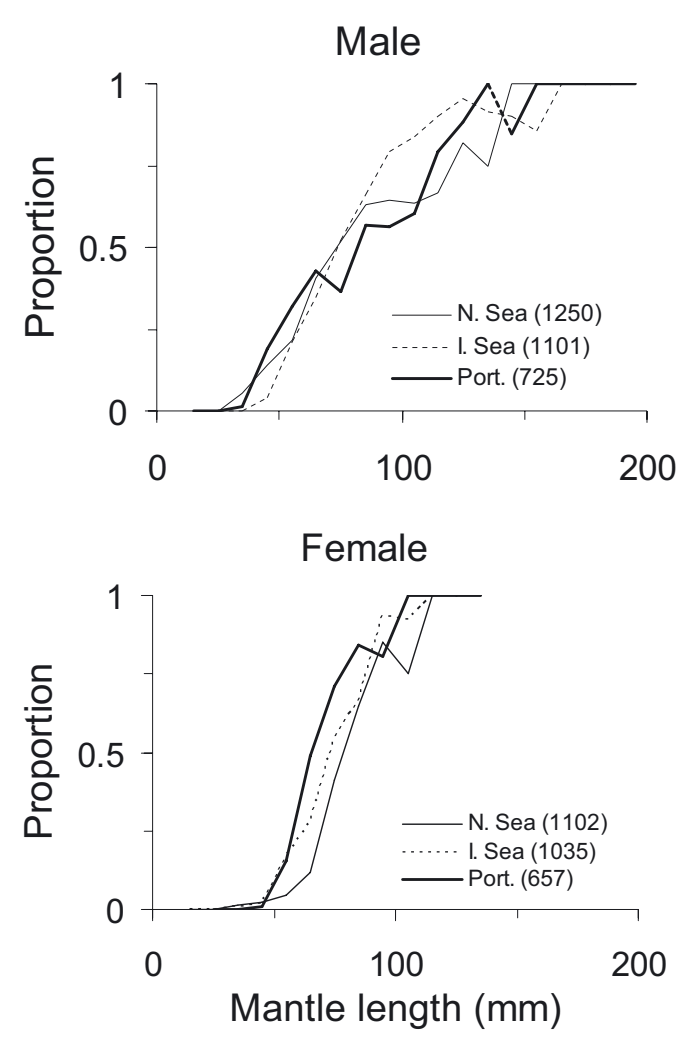

Fig. 4. Overall proportions of mature Alloteuthis subulata observed (sample sizes in parentheses). very small oocytes $(<0.3 \mathrm{~mm}$ diameter). Three to four modal size-classes of oocytes were apparent in each ovary.

\section{Discussion}

The opportunistic nature of this study, and the fact that different vessels and gears were used to collect the samples, should be considered when interpreting the results presented here. Nevertheless, it was apparent that a number of obvious, significant spatial and temporal trends in growth and reproductive parameters were exhibited by the $A$. subulata population in the NE Atlantic.

The overall size distributions of A. subulata caught in the three areas were quite similar, given that different vessels and (bottom) gears were used. The smaller modal size observed in the Irish Sea sample is mainly due to the large numbers of immature squid caught during autumn in 1993 and 2000. The fact that this phenomenon was not observed in North Sea or in the Portuguese samples may be associated with differential efficiency of sampling of smaller animals, since relatively large numbers of immature squid were also caught in these areas during autumn.

Seasonal variation in sex ratios appear to be a common feature of loliginid populations, and may reflect differences in sampling bias and/or differential migratory patterns. For example, in Scottish waters, female Loligo forbesi may become more numerous (or aggregated) during the spawning season (Collins et al. 1999). 
Table 5. Seasonal size-at-maturity data recorded for female A. subulata.

\begin{tabular}{|c|c|c|c|c|c|c|c|c|c|c|c|}
\hline \multirow[b]{4}{*}{ Season } & \multirow[b]{4}{*}{ Area } & \multirow[b]{4}{*}{$N$} & \multicolumn{8}{|c|}{ FEMALES } & \\
\hline & & & \multirow{3}{*}{$\begin{array}{l}M L_{50} \\
(\mathrm{~mm})\end{array}$} & \multicolumn{8}{|c|}{ Size-at-maturity } \\
\hline & & & & \multicolumn{4}{|c|}{$M L(\mathrm{~mm})$} & \multicolumn{4}{|c|}{$W t(\mathrm{~g})$} \\
\hline & & & & $N$ & Mean & SD & Range & $N$ & Mean & SD & Range \\
\hline \multirow[t]{3}{*}{ Spring } & North Sea & 156 & 79 & 24 & 63.1 & 13.5 & $45-95$ & 21 & 5.2 & 2.0 & $2.9-10.8$ \\
\hline & Irish Sea & 668 & 78 & 371 & 90.0 & 11.9 & $58-125$ & 371 & 8.8 & 2.2 & $2.5-18.3$ \\
\hline & Portugal & - & - & - & - & - & - & - & - & - & - \\
\hline \multirow[t]{3}{*}{ Summer } & North Sea & 130 & 65 & 69 & 79.3 & 11.6 & $48-103$ & 69 & 7.3 & 2.8 & $1.6-15.0$ \\
\hline & Irish Sea & 269 & 58 & 202 & 75.8 & 12.7 & $40-113$ & 202 & 6.4 & 1.7 & $1.8-11.4$ \\
\hline & Portugal & 328 & 65 & 159 & 76.4 & 11.4 & $55-113$ & 112 & 6.6 & 1.7 & $4.0-12.2$ \\
\hline \multirow[t]{3}{*}{ Autumn } & North Sea & - & - & - & - & - & - & - & - & - & - \\
\hline & Irish Sea & - & - & 4 & 104.3 & 16.1 & 34-94 & 4 & 15.0 & 5.2 & $10.2-22.2$ \\
\hline & Portugal & 129 & 72 & 46 & 84.9 & 10.6 & $66-110$ & 20 & 9.1 & 1.7 & $6.0-12.2$ \\
\hline \multirow[t]{3}{*}{ Winter } & North Sea & 779 & 86 & 46 & 67.8 & 17.5 & $32-102$ & 44 & 5.8 & 3.0 & $1.5-14.8$ \\
\hline & Irish Sea & - & - & - & - & - & - & - & - & - & - \\
\hline & Portugal & 200 & 69 & 44 & 64.9 & 7.4 & $47-82$ & 39 & 5.3 & 1.1 & $3.2-8.2$ \\
\hline \multirow[t]{3}{*}{ Overall } & North Sea & 1102 & 77 & 139 & 72.7 & 15.6 & $32-103$ & 134 & 6.5 & 2.9 & $1.5-15.0$ \\
\hline & Irish Sea & 1035 & 72 & 577 & 85.1 & 14.0 & $34-128$ & 577 & 8.0 & 2.4 & $1.8-22.2$ \\
\hline & Portugal & 657 & 64 & 249 & 75.9 & 12.2 & $47-113$ & 171 & 6.6 & 1.9 & $3.2-12.2$ \\
\hline
\end{tabular}

Table 6. Inter-annual comparisons of $M L_{50}$ and mean $M L$ observed in A. subulata samples from the North Sea (1998-1999) and Irish Sea (1993-2000).

\begin{tabular}{lcccccccccc}
\hline Vessel & Area & Month & Year & Sex & $N$ & $M L_{50}$ & Mean & Modal & SD & Range \\
\hline \multirow{2}{*}{ Walther Herwig III } & \multirow{2}{*}{ North Sea } & January & 1998 & $\mathrm{M}$ & 315 & 50 & 60.9 & $61-70$ & 14.79 & $25-144$ \\
& & & 1999 & $\mathrm{M}$ & 639 & 75 & 62.6 & $61-70$ & 18.80 & $14-116$ \\
& & & & & & & & & & \\
& & & 1998 & $\mathrm{~F}$ & 282 & 87 & 53.0 & $51-60$ & 10.93 & $26-97$ \\
& & 1999 & $\mathrm{~F}$ & 446 & 86 & 53.2 & $51-60$ & 14.72 & $14-102$ \\
\hline \multirow{3}{*}{ Lough Foyle } & \multirow{2}{*}{ Irish Sea } & \multirow{2}{*}{ March } & 1993 & $\mathrm{M}$ & 221 & 95 & 86.6 & $81-90$ & 19.59 & $49-132$ \\
& & & 2000 & $\mathrm{M}$ & 557 & 85 & 100.8 & $91-100$ & 23.42 & $44-175$ \\
& & & 1993 & $\mathrm{~F}$ & 221 & 81 & 74.1 & $61-70$ & 13.15 & $44-125$ \\
& & & 2000 & $\mathrm{~F}$ & 462 & 81 & 86.2 & $81-90$ & 12.69 & $49-122$ \\
\hline
\end{tabular}

The smaller maximum sizes exhibited by females in the three areas may be due to a greater investment of energy in reproduction, associated with vitellogenesis and the development of accessory reproductive organs.

The polymodal size-frequency distributions observed in all three areas (Fig. 2) indicate that, across the geographic range of A. subulata, several recruitment events may occur annually. The greater complexity of length-frequency distributions observed in southern waters may reflect a latitudinal trend, possibly associated with higher sea temperatures and a longer growing season at lower latitudes. Cephalopod growth rates are strongly influenced by water temperature (Forsythe and Van Heukelem 1987) and therefore differences in SST may also explain the differences in mean size observed in squid caught in the Irish Sea during 1993 and 2000. It is also possible that, in Portuguese waters and, to a lesser extent, the Irish Sea, an extended spawning season and associated hatching times leads to a number of micro-cohorts in the population each year. There is also some suggestion of micro-cohorts in the North Sea during summer, although these are less clearly defined than those observed in the Irish Sea and Portuguese waters. Distinct micro-cohorts have been observed in samples of other loliginid squid species, notably Loligo forbesi (Collins et al. 1999).

Relatively large numbers of small squid (both sexes) were caught during autumn, indicating a major recruitment event in all three areas. An apparent trend of decreasing recruitment period at high latitudes may be linked to either spawning activity 
Table 7. Potential fecundity $(P F)$ estimates and mean egg size (diameter) for mature female A. subulata from the Irish Sea.

\begin{tabular}{|c|c|c|c|c|c|c|c|}
\hline \multirow[b]{3}{*}{ Specimen } & \multirow{3}{*}{$\begin{array}{c}M L \\
(\mathrm{~mm})\end{array}$} & \multirow{3}{*}{$\begin{array}{l}B W \\
(\mathrm{~g})\end{array}$} & \multicolumn{3}{|c|}{ Egg counts } & \multirow{2}{*}{\multicolumn{2}{|c|}{$\begin{array}{l}\text { Mean egg size } \\
(\mathrm{mm})\end{array}$}} \\
\hline & & & Ovary & Oviduct & Overall & & \\
\hline & & & (ova/oocytes) & (ova) & $(P F)$ & Oocyte & Ova \\
\hline 1 & 92 & 11.2 & 6820 & 318 & 7138 & 0.61 & 1.70 \\
\hline 2 & 108 & 13.0 & 3809 & 471 & 4280 & 0.60 & 1.90 \\
\hline 3 & 108 & 12.9 & 7852 & 304 & 8156 & 0.35 & \\
\hline 4 & 92 & 10.0 & 13456 & 46 & 13502 & 0.21 & \\
\hline 5 & 80 & 7.3 & 2135 & 48 & 2183 & 0.47 & \\
\hline 6 & 121 & 13.9 & 6819 & 139 & 6958 & 0.33 & \\
\hline 7 & 114 & 12.8 & 4063 & 120 & 4183 & 0.45 & \\
\hline 8 & 92 & 8.3 & 6660 & 98 & 6758 & 0.39 & \\
\hline 9 & 91 & 8.8 & 5533 & 145 & 5678 & 0.32 & \\
\hline 10 & 94 & 9.7 & 2312 & 279 & 2591 & 0.51 & \\
\hline 11 & 92 & 11.3 & 3296 & 163 & 3309 & 0.69 & \\
\hline (Overall) & (99) & (10.8) & (5705) & (194) & (5899) & $(0.45)$ & (1.55) \\
\hline
\end{tabular}

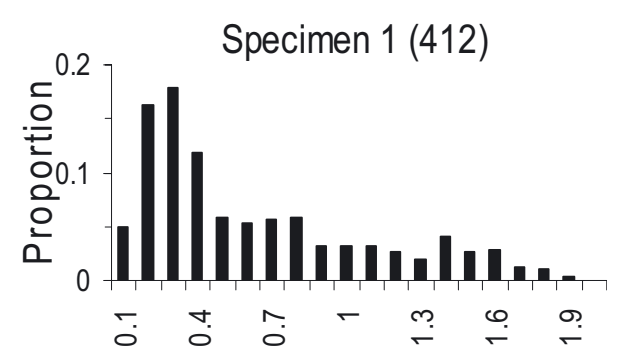

Specimen 2 (306)

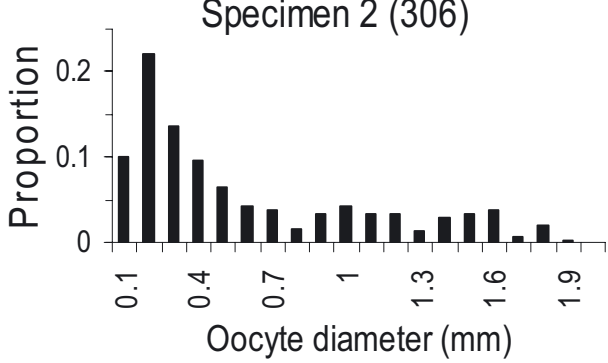

Fig. 5. Egg size-frequency distributions observed in ovaries from two A. subulata specimens (sample sizes in parentheses).

or spawning success. The observed predominance of immature squid in the North Sea and Irish Sea during autumn may reflect the occurrence of a single, major annual recruitment event at higher latitudes. In the North Sea, the spawning season is relatively short and its timing is in accordance with the period when hatchlings appear in plankton samples (June-July) (Yau 1994). The spawning season in the Irish Sea occurs during spring and summer, although there may be an additional, minor event in autumn (Nyegaard 2001), not observed in our data sets. By contrast, in Portuguese waters, the occurrence of small, immature squid throughout the year may be associated with several, distinct spawning events at lower latitudes (e.g. the high proportions of mature females in May, August, and November). Similarly, according to Rodhouse et al. (1988) there may be at least three distinct groups of A. subulata that spawn in spring, summer, and autumn in the English Channel.
The greater relative weights and early (spring) maturity observed in Portuguese waters may be a consequence of faster development times associated with higher water temperatures. On the other hand, the length of the spawning season in the areas analysed seems to be related not only to the latitudinal trend in the favourable temperature range, but also to the duration of the productivity cycle in each area. Portuguese waters, within the western Iberian upwelling system (Relvas et al. 2007), are characterized by moderate temperatures and abundant food during most of the year, which favours growth and reproduction. The spatial differences in the length of the spawning season and timing of spawning peaks of $A$. subulata inferred from our results are very similar to those of the sympatric squid Loligo vulgaris (Moreno et al. 2002), and provide further evidence of the plasticity of loliginid squid life cycles in relation to local environmental conditions (Boyle et al. 1995).

Distinct (batch) spawning events could explain the polymodal egg size-frequency distributions observed in ovary samples from the Irish Sea (Fig. 6). Our estimates of potential fecundity (2200-13500 eggs per female) are similar to those reported previously for the close congener, Alloteuthis media in the eastern Mediterranean (Laptikhovsky et al. 2002). The mean size of mature ova (1.6 $\mathrm{mm}$ in the Irish Sea and $1.5 \mathrm{~mm}$ in Portuguese waters) observed during the present study also falls within the range of $1.5-2.3 \mathrm{~mm}$ reported for $A$. media by Laptikhovsky et al. (2002).

In conclusion, our results provide evidence of latitudinal effects on growth, maturation and reproduction of $A$. subulata in the NE Atlantic, although some caution in interpretation is needed due to possible sampling error associated with opportunistic studies involving different vessels and gears must be considered. An observed increase in complexity of population structure in warmer waters suggests that water temperature may be the main factor involved, possibly acting through shorter incubation times, faster growth and maturation rates and extended spawning periods.

Acknowledgements. Funding and support of this study was provided by the SEAFISH and ANIMATE projects. Samples of A. subulata 
from the different study areas were kindly supplied by Fisheries Research Services (FRS, Scotland), Bundesforschungsantalt für Fishcherei (BFAFi, Germany), Department of Agriculture and Rural Development (DARD, Northern Ireland) and Instituto Nacional de Recursos Biológicos (INRB/L-IPIMAR, Portugal). We would also like to thank two anonymous referees for their constructive criticisms of the draft manuscript.

\section{References}

Anderson F.E., Pilsits A., Clutts S., Laptikhovsky V., Bello G., Balguerías E., Lipinski M., Nigmatulin C., Pereira J.M.F., Piatkowski U., Robin J.P., Salman A., Tasende M.G., 2008, Systematics of Alloteuthis (Cephalopoda:Loliginidae) based on molecular and morphometric data. J. Exp. Mar. Biol. Ecol. 364, 99-109.

Boyle P.R., 1983, Eledone cirrhosa. In: Boyle P.R. (Ed.), 1987, Cephalopod Life Cycles: Vol. 2. Comparative Reviews. Academic Press, London, pp. 365-386.

Boyle P.R., Ngoile M.A.K. 1993, Population variation and growth in Loligo forbesi (Cephalopoda: Loliginidae) from Scottish waters. In: Okuntani T., O’Dor R., Kubodera T. (Eds.) Recent Advances in Cephalopod Fisheries Biology. Tokai University Press, Tokyo, pp. 48-59.

Boyle P.R., Pierce G.J., Hastie L.C., 1995, Flexible reproductive strategies in the squid Loligo forbesi. Mar. Biol. 121, 501-508.

Collins M.A., Boyle P.R., Pierce G.J., Key L.N., Hughes S.E., Murphy J., 1999, Resolution of multiple cohorts in the Loligo forbesi population from the west of Scotland. ICES J. Mar. Sci. 56, 500-509.

Daly H.I., Pierce G.J., Santos M.B., Roye, J., Cho S.K., Stowasser G., Robin J.-P., Henderson S.M., 2001, Cephalopod consumption by trawl-caught fish in Scottish and English Channel waters. Fish. Res. 52, 51-64.

Fernandes A.C., Barbosa S., Silva D., Pestana G., 2008, Composição dos desembarques e das rejeições por espécie da frota portuguesa de arrasto de fundo. Relat. Cient. Téc. IPIMAR, Série digital (http://ipimar-iniap.ipimar.pt), 46 1-38.

Forsythe J.W., Van Heukelem W.F., 1983, Growth. In: Boyle P.R. (Ed.), 1987. Cephalopod Life Cycles: Vol. 2. Comparative Reviews. Academic Press, London, pp. 135-156.

de Heij A., Baayen R.P., 1999, Seasonal distribution of the cephalopod Alloteuthis subulata in the central and southern North Sea. Basteria 63, 129-138.
Hislop J.R.G., Robb A.P., Bell M.A., Armstrong D.W., 1991, The diet and food consumption of whiting (Merlangius merlangus) in the North Sea. ICES J. Mar. Sci. 48, 139-156.

Laird L.M., Priede I.G., 1986. Notes on a Stereological Technique for the Estimation of the Number of Oocytes in the Ovary of Mackerel (Scomber scombrus). Unpubl. Res. Rep., University of Aberdeen.

Laptikhovsky V., Salman A., Önsoy B., Katagan T., 2002, Systematic position and reproduction of squid of the genus Alloteuthis (Cephalopoda: Loliginidae) in the eastern Mediterranean. J. Mar. Biol. Assoc. UK 82, 983-985.

Moreno A., 1990, Alloteuthis spp. (Cephalopoda: Loliginidae), um Recurso Natural Subexplorado. Aspectos da sua Biologia. Unpubl. Diplom. Thesis, Universidade de Lisboa.

Moreno A., 1995, Aspectos da biologia de Alloteuthis subulata e distribuição de Alloteuthis spp. (Cephalopoda: Loliginidae) nas águas portuguesas. Relat. Cient. Téc. Inst. Invest. Pescas Mar. 8, $1-16$.

Moreno A., Pereira J., Arvanitidis C., Robin, J.-.P., Koutsoubas D., Perales-Raya C., Cunha M.M., Balguerias E., Denis V., 2002, Biological variation of Loligo vulgaris (Cephalopoda: Loliginidae) in the Eastern Atlantic and Mediterranean. Bull. Mar. Sci. 71, 515-534.

Nyegaard M., 2001, Analysis of Reproductive Behaviour, Demography, Diet and Spatial Distribution of the European Common Squid (Alloteuthis subulata) in the Irish Sea. Unpubl. M.Sc. Thesis, University Troms $\varnothing$.

Relvas P., Barton E.D., Dubert J., Oliveira P.B., Peliz A., Silva J.C.B., Santos A.M.P, 2007, Physical oceanography of the western Iberia ecosystem: Latest views and challenges, Prog. Oceanogr. 74, 149-173.

Rodhouse P.G., Swinfen R.C., Murray A.W.A., 1988, Life cycle, demography and reproductive investment in the myopsid squid Alloteuthis subulata. Mar. Ecol. Prog. Ser. 45, 245-253.

Roper C.F.E., Sweeney M.J., Nauen C.E., 1984, FAO Species Catalogue Vol. 3. Cephalopods of the World. An annotated and illustrated catalogue of species of interest to fisheries. FAO Fish. Synop. 125(3), Rome.

Velasco F., Olaso I., Sánchez F., 2001, The role of cephalopods as forage for the demersal fish community in the southern Bay of Biscay. Fish. Res. 52, 65-77.

WGCEPH, 2005, Report of the Working Group on Cephalopod Fisheries and Life History. WGCEPH Report, International Council for the Exploration of the Sea, Copenhagen.

Yau C., 1994, The Ecology and Ontogeny of Cephalopod Juveniles in Scottish Waters. Unpubl. Ph.D. Thesis, University of Aberdeen. 